\title{
Causality between indirect translation and translator disparity
}

\author{
B. O. Pliushch \\ Assistant Professor, Taras Shevchenko National University of Kyiv, Kyiv, Ukraine \\ Corresponding author. E-mail: danapliushch@outlook.com
}

Paper received 29.03.19; Accepted for publication 10.04.19.

\section{https://doi.org/10.31174/SEND-Ph2019-195VII59-13}

\begin{abstract}
The article focuses on translator disparity, indirect translation and their causal relationship in terms of the translation of the so-called small literatures. It considers the role of a translator disparity in the representation of Ukrainian literary prose as well as explores its correlation with other marginal translation practices such as indirect translation. Ukrainian literature represents an illustrative material of this article since Ukrainian does not belong to the range of global languages and is rarely learned as a foreign language by English native speakers.
\end{abstract}

Keywords: translator disparity, indirect translation, discordant translation, translator ethics, telos, translator responsibility.

When considering translation from minority/ minor languages, translator disparity is inevitable. Translator disparity means inequality of limitations, requirements and conditions of work of a translator from a minority language. This inequality stems from the comparison to conditions and requirements of the work of translators from any global language, such as English, French, German etc. J. Spirk states that "there is little doubt that the constraints imposed on translators from major languages also apply to translators from minor languages, but it could be hypothesized, that while probably not different in absolute terms, these constraints may be different in degree" [12, p. 130]. Difference in constraints entails also difference in conditions and/or requirements to a translator, his/her telos [4, p.17], responsibility and translation pact.

The regulatory factor of teloi (pl. of telos) - reasons, including personal, for making choice to undertake a translation - is translator responsibility. This concept has been elaborated by A. Pym in his book "On Translator Ethics" (2012). He points out that translator responsibility is a "basis of ethics" [10, p. 67] and lies within the scope of interculturality and thus is regulated not only by the target culture laws and rules. A. Pym outlines translator's responsibility to the original text's content, to the profession and the client. In the three chapters of his book, the translation scholar showcases the connection between responsibility and ethics, stating that the ethical responsibility of a translator is "to prevent the translating language and culture from effacing the linguistic and cultural differences of the source text, its foreignness" [10, p. 106]. In the given article the term translator responsibility is used in this meaning.

Thus, translator disparity enables telos, devoid of ethical constraints. A translator can be motivated solely by economic capital (according to P. Bourdieu) and/ or work for those, who exploit translation as a means of propaganda. Therefore, translator disparity can lead to the absence of any ethical responsibility. It may vanish due to the minor status of a language. Moreover, the status of a language also impacts the establishing of translation pact. C. Alvstad states that readers perceive the words of a translation as the ones belonging to the author (not a translator) not only because of the general cultural norm or inability to realize that a certain text is a translation but because the rhetorical structure of the text of translation induces readers to perceive a translated text as author's, despite the obvious discursive presence of a translator [1, p. 274].
One of the constituents of a translation pact is framing, created by paratexts, showing thus different types of agents of translation. M. Baker considers framing to be a translator's tool, which gives him/her ability to intervene into and change narratives [2]. T. Hermans states that "framing is everything if we're talking about conflict of values" [7, p. 287]. The establishing of translation pact or its absence - discordant translation - depends on framing. According to T. Hermans, it is one of the tools of "signaling by a translator the difference between his/her views and the ones expressed in the text of translation [...], which results in a discordant translation" [7, p. 292].

It stands to reason that discordant translation as an alternative to translation pact is not always easy to detect. For instance, the translation pact can be well established but due to a specific framing the translation can be represented as such that has nothing in common with the source text or even its culture. For instance, a story "Zakhar Berkut" by a Ukrainian writer I. Franko in the indirect German translation is presented as a work of Russian literature. This case illustrates the elimination of translator responsibility in terms of translation from minor languages as well as the infringement of ethical norms in framing. Such changes in the telos of a translator, requirements to his/ her responsibility and abuse or manipulation of translation pact are unaccepted in translation from global languages. For example, in the interview for "The Guardian" (as of 24 ${ }^{\text {th }}$ July 2016) Ann Goldstein, known for her English translations of novels by Italian author Elena Ferrante, confessed: "I'm not a novelist. I don't feel like I'm rewriting, or creating something new. I don't feel it's my job to do that. For the third or fourth draft, I might work without the text. But in the end, I go back to it, to make sure I haven't gotten too far away from it." In the same interview Edith Grossman, who continues work of Gregory Rabassa, translating masterpieces of Spanish literature (works by M. Cervantes, M. Vargas Llosa, G. Garcia Marquez etc.) into English, argues that translation is "an aural/oral practice. You have to be able to hear the language of the original. You have to be able to hear the tonalities, what the language indicates about the intelligence or class of the speaker" [5]. Thus, translators of global literatures emphasize their respect to the original by taking into consideration not only grammatical and stylistic peculiarities of the original text as well as author's implications. 
Translator disparity as an inequality of translation constraints can produce different marginal practices in translation. Indirect translation - translation through the mediating language - is one of them. Despite its marginal status, some translation scholars defend its right to existence.P. Zaborov, in his article on Zwischenübersetzung, devoted to Russian mediation, states that "it is no exaggeration to argue that for a lot of "national literatures" Russian mediation gave way abroad" [14, p. 2072]. R. Lie also expresses a positive outlook on indirect translation, stating that due to its existence "texts of a more obscure national origin became available to the international readership" [9, 709]. M. Ringmar states that "writers who are writing in peripheral languages realize that very often the only alternative of indirect translation is no translation at all" [11, p, 142]. That explicates P. Zaborov's and R. Lie's argumentation, that is that the peripheral status of the language makes even an indirect translations from it a desirable event for the source culture.

All the above-mentioned concepts of sociological and narrative approaches to translation, such as translator ethics, translator responsibility, telos, narrative framing, translation pact, shape translator disparity. And indirect translation is caused by translator disparity. The case of Ukrainian literature in translation into global languages is a good example of translator disparity at work since the peripheral status of Ukrainian language and literature gives way to indirect translations as alternative to the total absence of translations. It results into unequal requirements to a translator from Ukrainian and thus changes his/ her telos and responsibility.

In 1975 "Svoboda Press" publishing house (New Jersey, USA) published a collection of works by Vasyl Symonenko, a famous Ukrainian poet, and their English translations ("Granite Obelisks" [13]). It is stated on the cover that selection, translation and footnotes were done by A. M. Fr.-Chyrovskyi. The translator dedicated the edition to God, Ukraine, Vasyl Symonenko and his parents. The small paratext can undermine translation pact due to its excessive sentimentality or modesty of the translator. The information about the translator, contained inside the book, doesn't add much value to the credibility of translator's competence, since it is stated there that Andrew Maria Fr.-Chyrovskyi is a student of a university in Rome (being 19 years old) but the main focus is on his parents (father is a professor and mother is a librarian). It stands to reason that the main aim of the paratext is to reassure the reader that the text of translation can be "trusted". There is also extra information about the translator's hobbies such as writing music and literary works and his dreams about publishing his own collection of prose. Thus, the telos of the translator becomes clearer missionary work and partly work for "symbolic capital" [3, p. 130] - for his own name. Even the young age and certain professional inexperience of the translator are transformed into advantages by such framing since they incur desire to check the quality of his work and, thus, to read the translation.

The above-mentioned example illustrates the entity of translator disparity although the translation is direct. Nevertheless, indirect translation represents one of the brightest manifestations of translator disparity. In USSR the mediating language for translation of Ukrainian literature was Russian. All translations (direct into Russian and indirect from Russian into other languages) were published in Moscow. For example, drama "Ukradene schastia" ("Stolen happiness", 1894) by I. Franko was translated into Spanish in 1958 and published by Moscow publishing house "Ediciones en lenguas extranjeras". It is clearly stated that the work was translated from Russian by J. Lopez Ganivet. Same way it is clearly stated on the published edition of the English translation (1957) of I. Franko's story "Boa Constrictor" (1878) that it was translated from Russian by F. Solasko. Moreover, the English translation of the story is also an instance of L2 translation since English is a foreign language for F. Solasko. Thus, we observe conflation of two undesirable translation practices in one translation text. M. Ringmar argues that "indirect translation can be used as an instrument of control of the target text due to political or religious reasons $[\ldots]$ it is most probable that this aspect played a critical role in an often use of Russian as a mediating language in the post-Soviet countries" [11, p. 7]. For instance, Azerbaijani scholar H. Isaxanali in his article on the history of translated Azerbaijani poetry claims that in the XX century "works by Azerbaijani writers and poets were translated into Russian and afterwards into other Soviet nations' and foreign languages" [8, p. 319]. Y. Gambier states that in the case of translation of postSoviet countries' literature "Russian was effectively used as a relay language" [6, p. 59]. And it really was the case. In the period of 1950-1980s English translations of works by Ukrainian authors were published by the Moscow publishing house "Foreign Languages Publishing House", which partly explains the open reference to indirect translation from the already existing Russian translations. And there are a lot of examples of such editions: M. Stelmach "Let the Blood of Man not Flow", translated from Russian by Eve Hannig and Olga Shartse, 1962 (М. Стельмах “Кров людська - не водиця"); М. Kotsiubynskyi "Chrysalis and Other Stories", trans. from Russian by Jacob Guralsky, 1958 (М.Коцюбинський “Лялечка та інші оповідання"); O. Korniichuk "Wings", trans. from Russian by John Biblons, 1960 (О.Корнійчук “Крила”); O. Honchar "The shore of Love", trans. from Russian by David Sinclair-Loutit, 1980 (О. Гончар “Острів любовi"); O. Honchar "Short stories", trans. from Russian by V. Shneerson, 1956 (О. Гончар “Оповідання”); I. Franko "Boa Constrictor and other stories", trans. from Russian by Fainna Solasko, 1957 (I. Франко "Воа Constrictor та інші оповідання") etc. As we can see, they all are marked by a clear indication of being translated indirectly from Russian. Therefore, Russian translation served as an original text for translations into English.

However, not only Russian served as a relay language for the foreign editions of works by Ukrainian authors. For example, English translation of the novel "Tyhrolovy" (1944) by I. Bahriany - "The hunters and the hunted" Ivan Bahriany, Burns and Mac Eachern in Toronto, 1954, 270 p. - served as a source text for German ("Das Gezetz der Taiga", Iwan Bahriany, Styria in Köln, 1961), Dutch ("Vlucht in de Taiga", Iwan Bahrjany, Prisma Boeken, 1959), Danish and other languages. Although the published editions of the translations do not contain any reference to the texts being translated indirectly. The information about indirect translation in this case can be ob- 
tained through the personal correspondence of the author and his friend, where he mentions discussions with different translators concerning the proximity of the English translation to the original text. Thus, translator disparity shows itself in the author's acceptance of indirect translation of his work.

In conclusion it can be said that the examples discussed in the given article show how translator disparity operates and impacts the potential quality of a translation, for example, by causing indirect translation. It is a direct consequence of hegemony of some languages and literatures and creates an a priori inequality of constraints for a translator from minor languages. The logic and justification of such a status quo deserve scrutiny by further inquiries into the topic.

\section{REFERENCES}

1. Alvstad C. The translation pact // Cecilia Alvstad // Language and Literature. Journal of the Poetics and Linguistics. Special issue: Narration and Translation; [editor: Geoff Hall; assistant editors: Catherine Emmott, Joanna Gavins]. - London: Sage Publications Ltd., 2014. - Vol.23. - №3. - P. 270-284.;

2. Baker M. The Changing Landscape of Translation \&Interpreting studies / Mona Baker. - 2014. 23p.https://www.academia.edu/6311299/The_Changing_Lan dscape_of_Translation_and_Interpreting_Studies;

3. Bourdieu P. The forms of capital/ P. Bourdieu // Handbook of Theory and Research foe The Sociology of Education (edited by J.G. Richardson). - New York: Greenwood Press, 1986. p. 241-258.

4. Chesterman A. The Name and Nature of Translator Studies / Andrew Chesterman// Hermes - Journal of Language and Communication Studies, 2009. - n.42. - P.13-20. http://download1.hermes.asb.dk/archive/download/Hermes42chesterman_net.pdf;

5. Cooke R. The subtle art of translating foreign fiction / R Cook // The Guardian, 24 July 2016 [Електронний ресурс]. - Режим доступу: https://www.theguardian.com/books/2016/jul/24/subtle-artof-translating-foreign-fiction-ferrante-knausgaard.;

6. Gambier Y. "Working with relay: An old story and a new challenge" / Y. Gambier, L. P. Gonzaléz // Speaking in Tongues: Language across Contexts and Users, University of Valencia Press. - 2003. - P. 47-66.;

7. Hermans T. Positioning translators: Voices, views and values in translation / Theo Hermans // Language and Literature. Journal of the Poetics and Linguistics Association; [edited by Geoff Hall, Catherine Emmott, Joanna Gavins]. - London: Sage Publications Ltd., 2014. - V.23 (№3). - P. 286-300.;

8. Isaxanali H. History and Policy of Translating Poetry: Azerbaijan and its Neighbors / H. Isaxanali // Meta: Journal des Traducteurs, Translator's Journal. Organe d'information et de recherché dans les domains de la traduction, de la terminologie et de l'interpretation. - Montreal: Les Presses de l’Université de Montreál, 2014. - Vol.59, n.2. - P. 310-329.;

9. Lie R. Indirect translation / R. Lie // Encyclopedia of Literary Translation into English (editor Olive Classe). - London, Chicago: Fitzroy Dearborn publishers. - Vol I (A-L). - 2000. - P.708-709.;

10. Pym A. On Translator Ethics. Anthony Pym; translated by Heike Walker, revised and updated by the author. - Amsterdam/ Philadelphia: John Benjamins Publishing Company, 2012. - 185 p.;

11. Ringmar M. Relay translation / Martin Ringmar // Handbook of translation studies; [edited by Yves Gambier, Luc van Doorslaer]. -Amsterdam/ Philadelphia: John Benjamins Publishing Company, 2012. - V.3. - P.141-144.;

12. Spirk J. Censorship, Indirect translations and Nontranslation: The (Fateful) Adventures of Czech Literature in $20^{\text {th }}$-century Portugal / J. Spirk. - Newcastle upon Tyne: Cambridge Scholars Publishing, 2014.- 190 p.;

13. Symonenko V. Granite Obelisks / Symonenko V.; selection, translation and explanation by A. M. Fr.-Chyrovsky. - New Jersey: Svoboda Press, 1975. - 143 p.;

14. Zaborov P. Die Zwischenübersetzung in der Geschichte der russischen Literatur / Petr Zaborov // Übersetzung. Translation. Traduction. Ein internationales Handbuch zur Übersetzungsforschung. An international Encyclopedia of Translation Studies. Encyclopidie internationale de la recherche sur la traduction; [herausgegeben von Harald Kittel, Armin Paul Frank, Norbert Greiner, Theo Hermans, Werner Koller, Jose Lambert, Fritz Paul; in Verbindung mit Juliane House etc.]. Berlin/ Boston: Walter de Gruyter, 2011. - Teilband 3. - S. 2068- 2074. 